\title{
Effect cardamom and cinnamon supplemented to soft cheese on tissues rats
}

\author{
${ }^{1}$ Salih, G.M., ${ }^{1}$ Jassim, M.A. and ${ }^{2,{ }^{*}}$ Saadi, A.M. \\ ${ }^{1}$ Department of Food Science, College of Agricultural, Tikrit University, Tikrit, Iraq \\ ${ }^{2}$ Department of Animal Production, Technical College of Agricultural, Northern Technical University, \\ Mosul, Iraq
}

\begin{abstract}
Article history:
Received: 10 September 2020

Received in revised form: 5

October 2020

Accepted: 23 October 2020

Available Online: 20

December 2020
\end{abstract}

Keywords:

Cardamom,

Cinnamon,

Liver functions,

Soft cheese

DOI:

https://doi.org/10.26656/fr.2017.5(1).501

\begin{abstract}
The purpose of this study was to produce soft cheese fortified with cardamom and cinnamon herbs and evaluate its effects on the vital tissues of male rats. Both herbs were used at concentration 0.2 and $0.4 \mathrm{~g} / 100 \mathrm{~g}$. Chemical composition and sensory evaluation of the soft cheese fortified with cardamom and cinnamon were performed immediately after manufacturing. The results showed the cells of the liver and kidney of male rats that consumed fortified soft cheese appeared healthy with a natural appearance. The sensory evaluation revealed the superiority of fortified soft cheese compared to the unfortified soft cheese. These results indicate the effectiveness of cardamom and cinnamon in preserving the active organ tissues of rats.
\end{abstract}

\section{Introduction}

Dairy products and their derivatives play a major role in nutrition (Al-Musawi and Al-Khalisy, 2016). These products varied and depend directly on cow, buffalo, sheep and goat milk, in addition to camel milk (Grzanich et al., 2017). Cheese is one of the important dairy products that take a wide field in human nutrition, and the cheese-making process is one of the oldest known methods for humans to manufacture a product that has a long preservation in addition to its high nutritional value compared to the original product raw milk (Kapoor et al., 2008; Rao and Gan, 2014; Butt et al., 2017). In general, cheese is an important food source that is produced continuously due to the large number of consumers also cheese is consider a substantial source of nutrients (proteins, fats, minerals, vitamin) (Lameire, 2014).

Medicinal plants play a major role in reducing diseases that affect the living organism. The cinnamon bark is one of the most important types of spices that are widely used throughout the world, not only to give flavor and good taste, it is also used for its important medical role (Vangalapati et al., 2012; Merkhan, 2019). From the most essential compounds in cinnamon that play an important role as antioxidants are cinnamaldehyde and trans-cin-aldehyde (Cin), with aromatic odors (Rao and Gan, 2014). The cinnamon bark also contains other compounds such as catechins and procyanidins. The two types of procyanidins, type-A and type-B, proven to have an effective role as antibacterial, antifungal, antioxidant and anti-diabetic (Kapoor et al., 2008; Gupta et al., 2011; Wang et al., 2011).

Cardamom is a medicinal plant, which is native to India and Southeast Asia, where it belongs to the ginger family. It contains compounds that stimulate the work of the heart and liver. Black cardamom seeds are used as a fungicide and stimulant for flavor, especially in the preparation of foods, and drinks. The cardamom contains countermeasures for oxidation and is usually used in foods to prevent oxidation that causes deterioration of the fatty compounds present in foods (Zaidan et al., 2019). Butylated hydroxytoluene (BHT), Butyl hydroquinone (TBHO) and Butylated hydroxyanisole (BHA) are considered as the most important antioxidant compounds in cardamom (Kapoor et al., 2008). Saadi et al. (2019) indicated that the percentage of solid materials, fat and protein in camel's milk was high. This was due to higher proportions in camel milk compared with sheep's milk. Similarly, the ratio of solids, protein, fat and ash in the resulting cheese. The objective of this study was to investigate the effect of consumption soft cheese fortified with different concentrations of cardamom and cinnamon on the vital tissues (liver and kidney) of male rats as well as the changes in chemical 
properties and sensory characteristics of the soft cheese.

\section{Materials and methods}

\subsection{Manufacturing soft white cheese with rennet}

Soft cheese was manufactured according to the steps by Al-Dahan (1983). Milk was pasteurized at $63^{\circ} \mathrm{C}$ for 30 mins and cooled to $35^{\circ} \mathrm{C}$. Then, the milk was salted with table salt $(2.5 \% \mathrm{~W} / \mathrm{W})$. The microbial rennet solution was prepared by dissolving the rennet tables in distilled water, stirred by hand for 5 mins and added into the milk. The milk was then incubated. The crude was removed after coagulation. To sperate the whey, the crude was casted into small woody molds lined with cheese cloth. The soft cheese was then kept in the refrigerator at $5^{\circ} \mathrm{C}$. The soft cheese was divided into five portions for the following fortification treatment: T1 control; T2 - treated with cardamom at concentration 0.2 $\mathrm{g} / 100 \mathrm{~g}$; T3 - treated with cardamom at concentration $0.4 \mathrm{~g} / 100 \mathrm{~g}$; T4 - treated with cinnamon at concentration $0.2 \mathrm{~g} / 100 \mathrm{~g}$; and $\mathrm{T} 5$ - treated with cinnamon at concentration $0.2 \mathrm{~g} / 100 \mathrm{~g}$

\subsection{Experimental animals}

The experimental animals used in this study were adult male rats (Rattus norvegicus) from the SpragueDawley strain at the age of 2-3 months with the initial body weights ranging from $90 \mathrm{~g}-155 \mathrm{~g}$ obtained from the College of Veterinary/University of Tikrit. The rats were housed in plastic cages with metal covers and floor covered with sawdust that are replaced every two days. The animals were subjected to laboratory conditions of 12-hour light-dark cycle at $25 \pm 2^{\circ} \mathrm{C}$. The animals were left for three days to adjust to the new conditions and to ensure that they were free of diseases. The animals received food and water ad libitum continuously in sufficient quantities throughout the breeding period. Each animal was individually weighed twice every week to monitor the increase and decrease in its weights.

\subsection{Experimental design}

The animals were divided into six groups of three rats each. Each group received diets composed of soft cheese fortified with medicinal plants (cardamom and cinnamon) in concentrations of 0.2 and 0.4 (g) respectively following:

Group 1 (negative control group): rats were fed on basal diet during the duration of the experiment.

Group 2 (positive control group): rats were fed on basal diet supplemented with soft cheese free of any additives throughout the experiment period.
Group 3: rats were fed on basal diet supplemented with fortified soft cheese with cardamom at concentration of $0.2 \mathrm{~g} / 100 \mathrm{~g}$.

Group 4: rats were fed on basal diet supplemented with fortified soft cheese with cardamom at concentration of $0.4 \mathrm{~g} / 100 \mathrm{~g}$.

Group 5: rats were fed on basal diet supplemented with fortified soft cheese with cinnamon at concentration of $0.2 \mathrm{~g} / 100 \mathrm{~g}$.

Group 6: rats were fed on basal diet supplemented with fortified soft cheese with cinnamon at concentration of $0.4 \mathrm{~g} / 100 \mathrm{~g}$.

All rats were fed twice every 12 hrs for 28 days consecutively. At the end of the experiment, the rats were sacrificed to obtain the livers and kidney for the histological examination. The weights of livers and kidney were obtained immediately and subsequently immersed in formalin at $10 \%$ concentration for 24 hours for fixation. The organs were washed with $10 \%$ ethyl and small pieces of tissues were taken and submerged in ascending ethyl concentration, i.e. $80 \%, 90 \%, 95 \%$ and $100 \%$, and finally dipped in a mixture of ethyl alcohol and xylol. Then, samples were embedded in paraffin wax (melting point: $60^{\circ} \mathrm{C}$ ), submerged in a new molten wax and left for 3 hours.

A section of $5 \mu \mathrm{m}$ thickness was cut and stained according to the method by Luna (1968). Wax was removed from the tissue sections of xylol and then, the glass slides were passed with descending grades of alcohol (100-30\%). The slides were then washed with distilled water and colored with hematoxylin for 4 mins. They were then washed with tap water for 15 mins and immersed in an alcoholic tincture for $5 \mathrm{~s}$ before rinsing with ethyl alcohol and xylene. DPX-mountant was then added on the slides and the slides were left to dry on the hot plate. The results were examined by Dr Iyad Hamid of the Ibrahim College of Veterinary - Tikrit University.

\subsection{Sensory evaluation of soft cheese and fortified}

Sensory evaluation of soft cheese and fortified soft cheese was carried out by 7 panellists from the Department of Food Science, Tikrit University, Iraq following the method by Arbuckle (1986). Scoring method was used to evaluate the following attributes: taste (out of 20 points), smell (out of 20 points), composition (out of 20 points), texture (out of 20 points), appearance (out of 10 points and colour (out of 10 points). 


\section{Results and discussion}

\subsection{Chemical composition of soft cheese}

The data of the chemical compositions of all treatments was presented in Table 1. The highest moisture content was the unfortified soft cheese $(56.13 \%)$ which was in agreement with the Iraqi standard specifications in 1988 while the moisture content for fortified soft cheeses were lower. From Table 1, the estimated protein content in unfortified soft cheese was $13.74 \%$. No significant difference was observed when compare to the fortified soft cheeses which was in agreement with the Iraqi standard specifications in 1988. Soft cheese produced by factories had a protein content of $13.18 \%$. The fat of unfortified soft cheeses was the lowest $(14.32 \%)$ while the highest fat content was measured in fortified soft cheese with $0.4 \mathrm{~g} / 100 \mathrm{~g}$ cinnamon. No significant difference was observed in the ash content for all samples.

\subsection{Effect of soft cheese fortified with medicinal plants} on the tissue sections of the liver and kidneys of male rats

\subsubsection{Liver}

Processed foods containing preservatives consumed daily can cause malignant tumors and liver problems. Livers is important in the human body where it supplies blood via the portal vein and the hepatic artery which makes it vulnerable to infection.

The microscopic examination of the liver on the Group 1 (negative control) rats showed enlarged hepatocytes, loose cytoplasm integration with significant decrease in pigmentation. The nuclei of the liver cells were thick, enlarged and some degenerated hepatocytes around central veins were observed (Figure 1A). The liver of Group 2 (positive control) rats appeared compact and the nuclei were dark. The blood granules were unclear due to the amplification of some hepatocytes and surrounding cells. In addition, the hepatic central and portal veins were congested with blood and some inflamed cells were observed (Figure 1B).

Figure 1C displays the liver sections of Group 3 (fortified soft cheese with $0.2 \mathrm{~g} / 100 \mathrm{~g}$ cardamom) rats.

The liver appear normal, red including hepatocytes radially distributed towards the centrilobular veins. Red blood cells were observed in the capillary lumen. Few Kupffer cells lined with blood sinusoids indicating infiltration or inflammation around the portal veins. Group 4 (fortified soft cheese with 0.4 g/100 g cardamom) rats had devastation of cytoplasm in the hepatocytes where it appeared large and thick nucleus with dark pigments, especially at the circumference of the liver (Figure 1D). Lymphocytes around the hepatocytes and blood vessels were also observed. The liver section of Group 5 (fortified soft cheese with 0.2 $\mathrm{g} / 100 \mathrm{~g}$ cinnamon) rats showed normal liver cells with some forming long rows, clusters and polygonal intervened with blood sinusoids lining the few Kupffer cells (Figure 1E). Abundant lymphocytes around the blood vessels and liver cells were detected. Normal histological liver structure (Figure 1F) was observed for Group 6 (fortified soft cheese with 0.4 g/100 g cinnamon) rats. The hepatic cells appeared normal, polygonal, contiguous, pigmented with the presence of few Kupffer cells lining the blood sinusoids to remove senescent red blood cells.
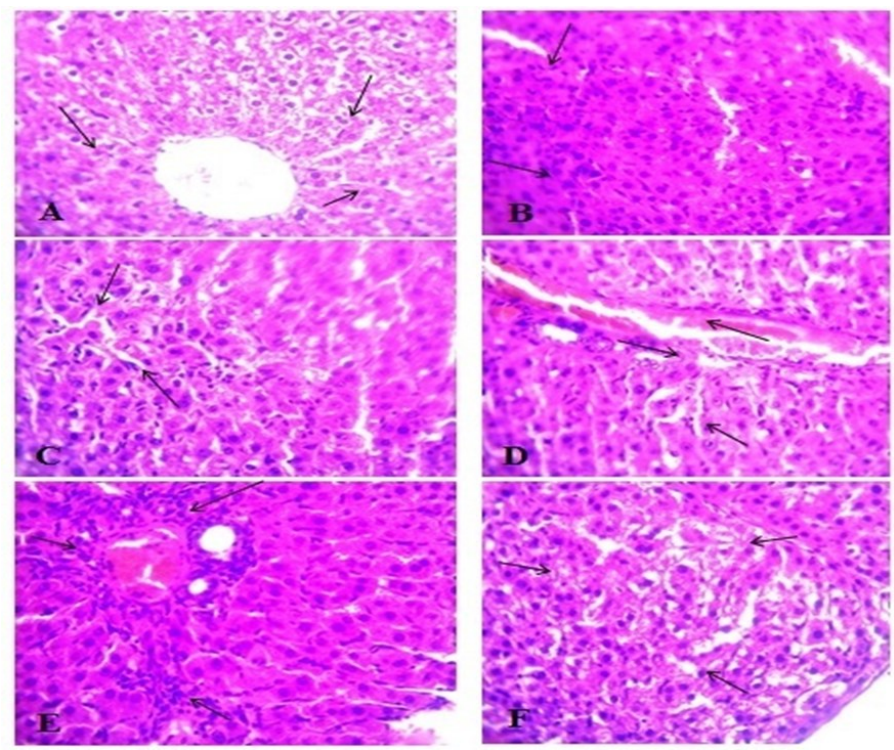

Figure 1. Liver micrograph of male adult rats of the following diet groups. A: Group 1 - negative control; B: Group $2-$ positive control; Group 3 - soft cheese with $0.2 \mathrm{~g} / 100 \mathrm{~g}$ cardamom; Group 4 - soft cheese with $0.4 \mathrm{~g} / 100 \mathrm{~g}$ cardamom; Group 5 - soft cheese with $0.2 \mathrm{~g} / 100 \mathrm{~g}$ cinnamon; and Group 6 - soft cheese with $0.4 \mathrm{~g} / 100 \mathrm{~g}$ cinnamon.

Table 1. Chemical composition of fortified soft cheese

\begin{tabular}{lccccc}
\hline Chemical tests & $\mathrm{T} 1$ & $\mathrm{~T} 2$ & $\mathrm{~T} 3$ & $\mathrm{~T} 4$ & $\mathrm{~T} 5$ \\
\hline Moisture & $56.13 \pm 1.74^{\mathrm{a}}$ & $42.31 \pm 16.30^{\mathrm{ab}}$ & $52.28 \pm 0.99^{\mathrm{ab}}$ & $40.59 \pm 0.45^{\mathrm{b}}$ & $51.84 \pm 1.53^{\mathrm{ab}}$ \\
Protein & $13.74 \pm 0.44^{\mathrm{a}}$ & $13.67 \pm 0.23^{\mathrm{a}}$ & $13.68 \pm 0.28^{\mathrm{a}}$ & $13.53 \pm 0.49^{\mathrm{a}}$ & $13.81 \pm 0.17^{\mathrm{a}}$ \\
Fats & $14.32 \pm 0.31^{\mathrm{b}}$ & $14.76 \pm 0.13^{\mathrm{a}}$ & $14.62 \pm 0.28^{\mathrm{ab}}$ & $14.76 \pm 0.15^{\mathrm{a}}$ & $14.90 \pm 0.95^{\mathrm{a}}$ \\
Ash & $5.82 \pm 10^{\mathrm{a}}$ & $5.83 \pm 0.3^{\mathrm{a}}$ & $5.86 \pm 0.01^{\mathrm{a}}$ & $5.89 \pm 0.01^{\mathrm{a}}$ & $5.92 \pm 0.01^{\mathrm{a}}$ \\
\hline
\end{tabular}

Values are expressed as mean \pm standard deviation. Values with different superscripts within row are significantly different $(\mathrm{P} \leq$ $0.05)$.

T1: Unfortified soft cheese, T2: fortified soft cheese with $0.2 \mathrm{~g} / 100 \mathrm{~g}$ cardamom; T3: fortified soft cheese with $0.4 \mathrm{~g} / 100 \mathrm{~g}$ cardamom, T4: fortified soft cheese with $0.2 \mathrm{~g} / 100 \mathrm{~g}$ cinnamon; T3: fortified soft cheese with $0.4 \mathrm{~g} / 100 \mathrm{~g}$ cinnamon. 
From the above results, it was found that cinnamon and cardamom have effective roles in improving liver and kidney tissue which agreed with the findings of Salih et al. (2018). Salih et al. (2018) mentioned that cardamom reduced creatinine and urea levels in kidney tissue as well as improve the glomerular functions and act as antioxidant due to polyphenol content.

\subsubsection{Kidney}

As shown in Figure 2A, the kidney micrograph of Group 1 rats showed normal size and shape kidneys. The renal cortex contained many glomeruli which were normal in size and shaped, surrounded by Bowman's capsule with the spread of many lymphocytes on its surface. The distal and proximal contortus tubule had normal histological structure with cubic cells with pale cytoplasm lining and large pyramidal shaped cells lining respectively. While the kidney micrograph of Group 2 rats showed some renal glomeruli in the cortex with the appearance of atrophy as a small mass in the middle of the Bowman's capsule space surrounded by large numbers of white blood cells and on its surface (Figure $2 b)$. The glomeruli and blood vessels were normal in the cortex.

In the kidney micrograph of Group 3 rats, the cortex appeared normal as a monolith block next to Bowman's capsule. Most of the proximal and distal tubular were of equal shape and structure (Figure 2C). The cortex of the Group 4 rats appeared natural and most of the cells appeared as a monolithic mass in their natural form of the Bowman wall surrounded by numerous white blood cells on its surface. Around the glomeruli and Bowman's capsule and the kidney medulla, different sizes of renal tubules surrounded by large numbers of connective tissue cells were observed (Figure 2D).

The renal glomeruli of the Group 5 rats appeared normal and compact. The distal and proximal contortus tubule appeared normal and compact. The medulla of the kidneys also appeared normal in structure (Figure 2E). The renal glomeruli of the Group 6 rats appeared normal to most cells with increased capsular space. The distal
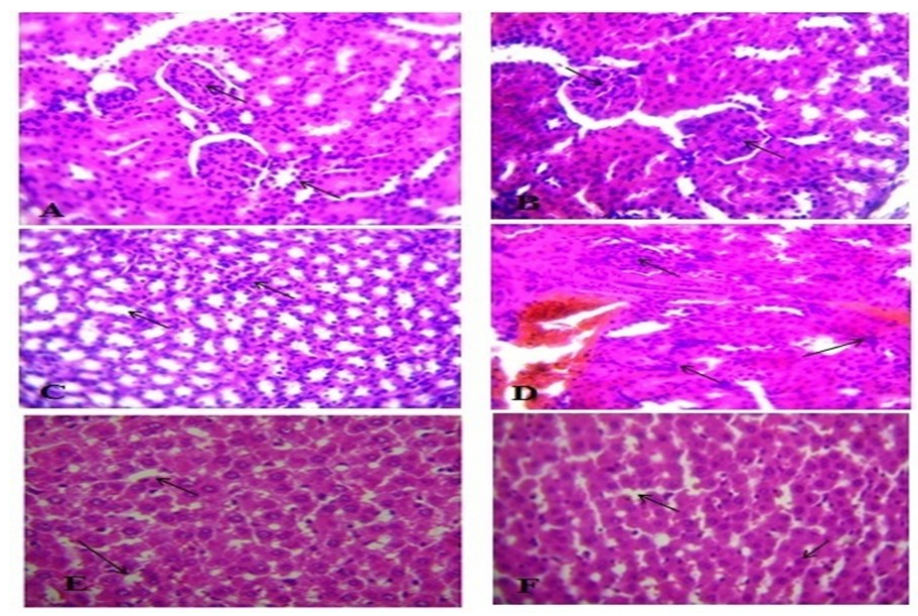

Figure 2. Kidney micrograph of male adult rats of the following diet groups. A: Group 1 - negative control; B: Group 2 positive control; Group 3 - soft cheese with $0.2 \mathrm{~g} / 100 \mathrm{~g}$ cardamom; Group 4 - soft cheese with $0.4 \mathrm{~g} / 100 \mathrm{~g}$ cardamom; Group 5 - soft cheese with $0.2 \mathrm{~g} / 100 \mathrm{~g}$ cinnamon; and Group 6 - soft cheese with $0.4 \mathrm{~g} / 100 \mathrm{~g}$ cinnamon.

and proximal contortus tubule and kidney medulla appeared normal (Figure 2F). This results were in agreement with Rahman et al. (2017) that the cardamom works to improve liver and kidney tissue through the presence of phenolic compounds in cardamom. A previous study on cardamom and cinnamon reported that the presence of antioxidants cinnamaldehyde (88.7\%), 1.8 cineole $(2.02 \%)$, and $\alpha$-Pinene $(1.45 \%)$ treats liver tissue (Mohammed et al., 2020). The cinnamon and cardamom have an active role as antioxidants which leads to improved tissues, including the kidneys and liver.

\subsection{Sensory evaluation of processed and fortified soft cheese with medicinal plants}

Table 2 shows the results of sensory evaluation of the unfortified soft cheese and fortified soft cheese with cardamom and cinnamon. The results of the non-treated soft cheese gave the lowest sensory evaluation scores. The reason for this may be due to the role of effective flavor compounds contained in both cinnamon and cardamom in improving the flavor characteristics of soft cheese which gave high results in values of flavor, texture, and composition according to Zangana and Al-

Table 2. Sensory evaluation values to the treatments of soft cheese supported with medicinal plants

\begin{tabular}{ccccccc}
\hline Treatments & Taste & Smell & Composition & Texture & Appearance & Colour \\
\hline T1 & $17.30 \pm 0.10^{\mathrm{a}}$ & $17.26 \pm 0.20^{\mathrm{a}}$ & $18.66 \pm 0.20^{\mathrm{a}}$ & $18.33 \pm 0.20^{\mathrm{a}}$ & $9.38 \pm 0.15^{\mathrm{a}}$ & $8.50 \pm 0.10^{\mathrm{a}}$ \\
T2 & $18.9 \pm 0.15^{\mathrm{c}}$ & $16.56 \pm 0.28^{\mathrm{b}}$ & $17.46 \pm 0.30^{\mathrm{b}}$ & $16.86 \pm 0.15^{\mathrm{b}}$ & $8.60 \pm 0.36^{\mathrm{b}}$ & $8.26 \pm 0.25^{\mathrm{a}}$ \\
T3 & $18.86 \pm 0.15^{\mathrm{c}}$ & $16.00 \pm 0.10^{\mathrm{c}}$ & $17.56 \pm 0.30^{\mathrm{b}}$ & $15.60 \pm 0.36^{\mathrm{c}}$ & $8.40 \pm 0.51^{\mathrm{b}}$ & $7.30 \pm 0.51^{\mathrm{b}}$ \\
T4 & $17.73 \pm 0.05^{\mathrm{b}}$ & $17.63 \pm 0.15^{\mathrm{a}}$ & $17.68 \pm 0.20^{\mathrm{b}}$ & $16.50 \pm 0.30^{\mathrm{b}}$ & $8.60 \pm 0.36^{\mathrm{b}}$ & $8.40 \pm 0.26^{\mathrm{a}}$ \\
T5 & $17.76 \pm 0.10^{\mathrm{b}}$ & $15.56 \pm 0.41^{\mathrm{c}}$ & $17.40 \pm 0.20^{\mathrm{b}}$ & $15.60 \pm 0.45^{\mathrm{c}}$ & $8.30 \pm 0.20^{\mathrm{b}}$ & $7.93 \pm 0.11^{\mathrm{a}}$
\end{tabular}

Values are expressed as mean \pm standard deviation. Values with different superscripts within row are significantly different $(\mathrm{P} \leq$ $0.05)$.

T1: Unfortified soft cheese, T2: fortified soft cheese with $0.2 \mathrm{~g} / 100 \mathrm{~g}$ cardamom; T3: fortified soft cheese with $0.4 \mathrm{~g} / 100 \mathrm{~g}$ cardamom, T4: fortified soft cheese with $0.2 \mathrm{~g} / 100 \mathrm{~g}$ cinnamon; T3: fortified soft cheese with $0.4 \mathrm{~g} / 100 \mathrm{~g}$ cinnamon. 
Safy (2018).

\section{Conclusion}

The results of this study showed soft fortified cheese by medicinal plants (cinnamon and cardamom) had an effective role in maintaining the safety of the liver tissue and its natural appearance. The sensory evaluation results showed the superiority of the soft cheese fortified with cinnamon and cardamom achieving the best sensory evaluation values for flavor, texture, smell, and composition.

\section{Acknowledgment}

The authors are very grateful to University of Tikrit / College of Veterinary and Northern Technical University, Technical agricultural university / Mosul, for their provide facilities, which helped to improve the quality of this work.

\section{References}

Al-Musawi, J. and Al-Khalisy, A. (2016). Effect of grind olive leaves supplementation in milk production and its components and some blood traits in native does. Iraqi Journal of Agricultural Science, 47(5), 13541359. https://doi.org/10.36103/ijas.v47i5.517

Al-Dahan, A.H.S. (1983). The manufacture of cheese and its types in the world. 1st ed. Mosul, Iraq: Dar Al-Hekma Press.

Arbuckle, W.S. (1986). Ice cream. $4^{\text {th }}$ ed., p. 186-187. Boston, Massachusetts: Springer. https:// doi.org/10.1007/978-1-4615-7222-0

Butt, M.M., Rose, S., Wilkins, S. and Haq, J.U. (2017). MNCs and religious influences in global markets. International Marketing Review, 34(6), 885-908. https://doi.org/10.1108/IMR-12-2015-0277

Grzanich, S.S., Klapholz, S. and Voccola, L. (2017). Soy -based cheese, impossible food inc., Patent Application Publication, US 2017/0172169 A1.

Gupta, C., Garg, A.P., Prakash, D., Goyal, S. and Gupta, S. (2011). Comparative study of cinnamon oil and clove oil on some oral microbiota. Acta Biomedica, 82(3), 197-199.

Kapoor, I.P.S., Singh, B., Singh, G., Isidorov, V. and Szczepaniak, L. (2008). Chemistry, antifungal and antioxidant activities of cardamom (Amomum subulatum) essential oil and oleoresins. International Journal of Essential Oil Therapeutics, 2(1), 29-40.

Lameire, N. (2014). Nephrotoxicity of recent anti-cancer agents. Clinical Kidney Journal, 7(1), 11-22. https:// doi.org/10.1093/ckj/sft135

Merkhan, K.Y. (2019). Milk production and body weight at weaning and their relationships with body and udder measurements in meriz goats. Iraqi Journal of Agricultural Sciences, 50(1), 480-486.

Mohammed, K.A., Ahmed, H.M., Sharaf, H.A., ElNekeety, A.A., Abdel-Aziem, S.H., Mehaya, F.M.and Abdel-Wahhab, M.A. (2020). Encapsulation of cinnamon oil in whey protein counteracts the disturbances in biochemical parameters, gene expression, and histological picture of the liver and pancreas of diabetic rats. Environmental Science and Pollution Research, 27 (3), 2829-2843. https://doi.org/10.1007/s11356-01907164-w

Rahman, M.M., Alam, M.N., Ulla, A., Sumi, F.A., Subhan, N., Khan, T., Bishwajit, S., Hemayet, H., Hasan, M.R. and Ashraful, M.D. (2017). Cardamom powder supplementation prevents obesity, improves glucose intolerance, inflammation, and oxidative stress in the liver of high carbohydrate high fat dietinduced obese rats. Lipids in Health and Disease, 16 (1), 151. https://doi.org/10.1186/s12944-017-0539-x

Saadi, A.M., Ali, F.F. and Jasim, A.Y. (2019). Study of the soft cheese composition produced from a mixture of sheep and camel milk at different storage periods using the enzyme trypsin and calcium chloride. Annals of Agri Bio Research, 24(2), 316-320.

Salih, F., Oumar, R. and Abaas, K. (2018). Effect of zinc salts fortification on nitrogen materials and rheologica characteristics of soft white Iraqi cheese. Iraqi Journal of Agricultural Sciences, 48(6), 17731781.

Vangalapati, M., Satya, S., Prakash, S. and Avanigadda, S. (2012). A review on pharmacological activities and clinical effects of cinnamon species. Research Journal of Pharmaceutical, Biological and Chemical Sciences, 3(1), 653-663

Wang, G.G., Lu, X. H., Li, W., Zhao, X. and Zhang, C. (2011). Protective effects of luteolin on diabetic nephropathy in STZ-induced diabetic rats. EvidenceBased Complementary Alternative Medicine, 2011, 323171. https://doi.org/10.1155/2011/323171

Zangana, B.S. and Al-Safy, N.H. (2018). Effect of adding two types of nutritional flavorings (cardamom and cinnamon) and their mixture to the diet in oxidation indicators for the meat of broilers chickens. Euphrates Journal of Agriculture Science, 10(3), 20-27.

Zaidan, S.A., Mohsin, K.H. and Muhsin, S.J. (2019). Effect of genotypes and tillage systems in some growth characteristics of Maize (Zea mays L.). Basrah Journal of Agricultural Sciences, 32(2), 715. https://doi.org/10.37077/25200860.2019.182 